\title{
Kocher-Debré-Semelaigne syndrome
}

\author{
Sanwar Agrawal, Prashant Thakur \\ Pediatrics Department, Ekta institute of Child Health, Shantinagar, Raipur, Chhattisgarh, India
}

Correspondence to Sanwar Agrawal, drsanwar50@gmail.com

\section{Summary}

A 4-year-old male child presented with severe growth failure and developmental delay. He had hypertrophy of calf muscles and the thyroid profile showed low levels of T3, T4 and markedly elevated level of thyroid-stimulating hormone thus confirming the presence of hypothyroidism. This combination of hypothyroidism and hypertrophy of muscles is classically described as Kocher-Debré-Semelaigne syndrome. This child was started on $50 \mu \mathrm{g}$ of levothyroxine.

\section{BACKGROUND}

Though it is a rare condition, the combination of features of hypothyroidism and calf muscle hypertrophy make it very easy to pick it up.

Thyroid hormone deficiency is a rare cause of acquired myopathy, comprising only $5 \%$ of the total cases.

This hypertrophy is reversible with treatment. Patients usually take months to recover, our patient, on first followup at 2 weeks showed clinical reduction in the bulk of muscle which was also observed by the parents.

\section{CASE PRESENTATION}

A 4-year-male child, born of non-consanguineous marriage was brought to us with history of growth failure and developmental delay. The parents took notice of the growth and developmental delay only in last 6 months. They were seeking advice in their village.

There was no history of frequent loose stools, urination or any febrile illness. The antenatal and birth history were unremarkable. There was no history of similar problems in the two siblings. The mother did not have any problem.

This child had coarse features, depressed nose bridge and a large tongue (figure 1).

He weighed $10 \mathrm{~kg}$, his height was $74 \mathrm{~cm}$ and head circumference $47 \mathrm{~cm}$ (all below third percentile). His height age corresponded to that of an year-old child's. His upper body segment was $44 \mathrm{~cm}$ and the lower segment was $30 \mathrm{~cm}$, with an upper and lower segment ratio of almost 1.5 (figure 2).

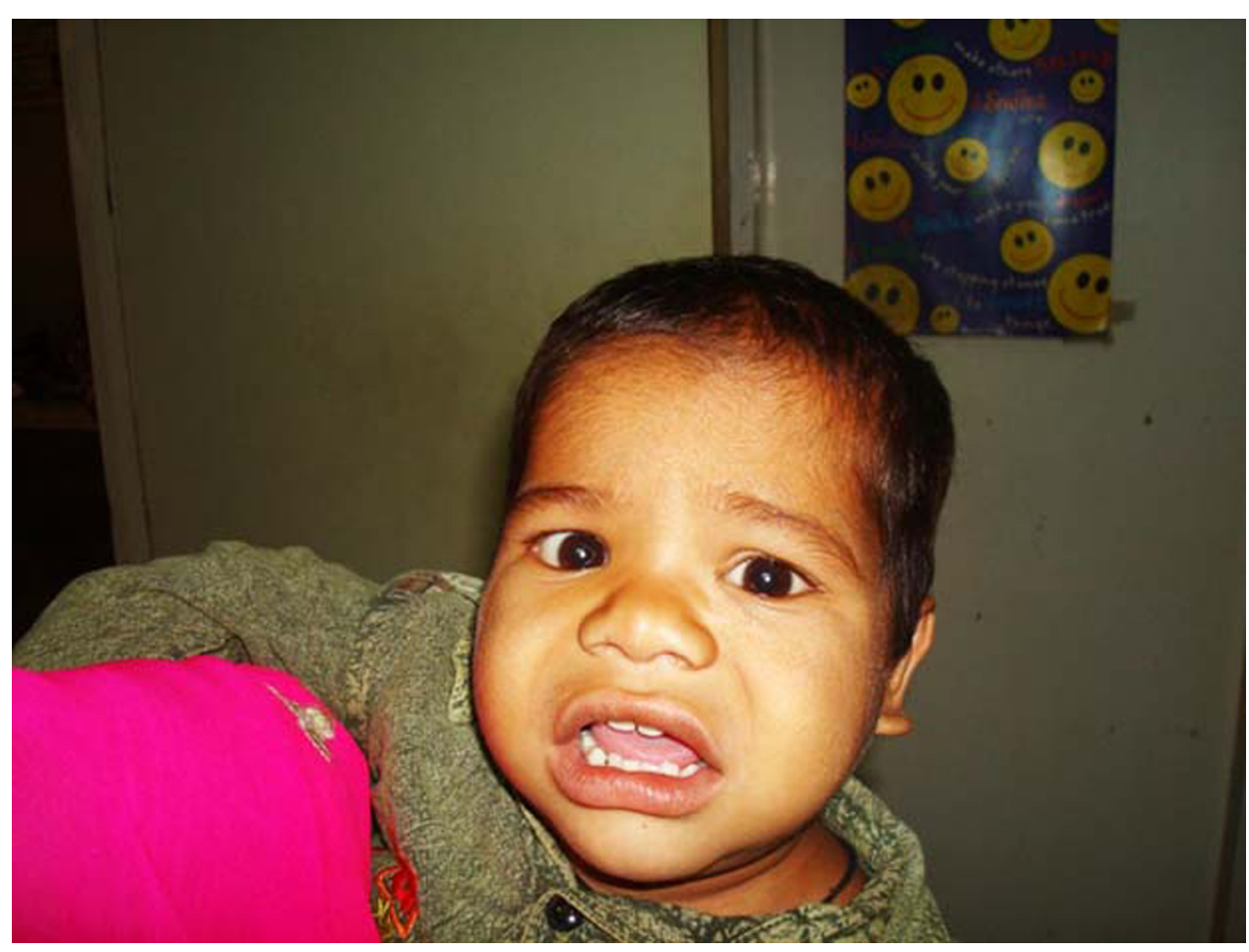

Figure 1 Coarse facies, large tongue, depressed nose bridge. 


\section{BMJ Case Reports}

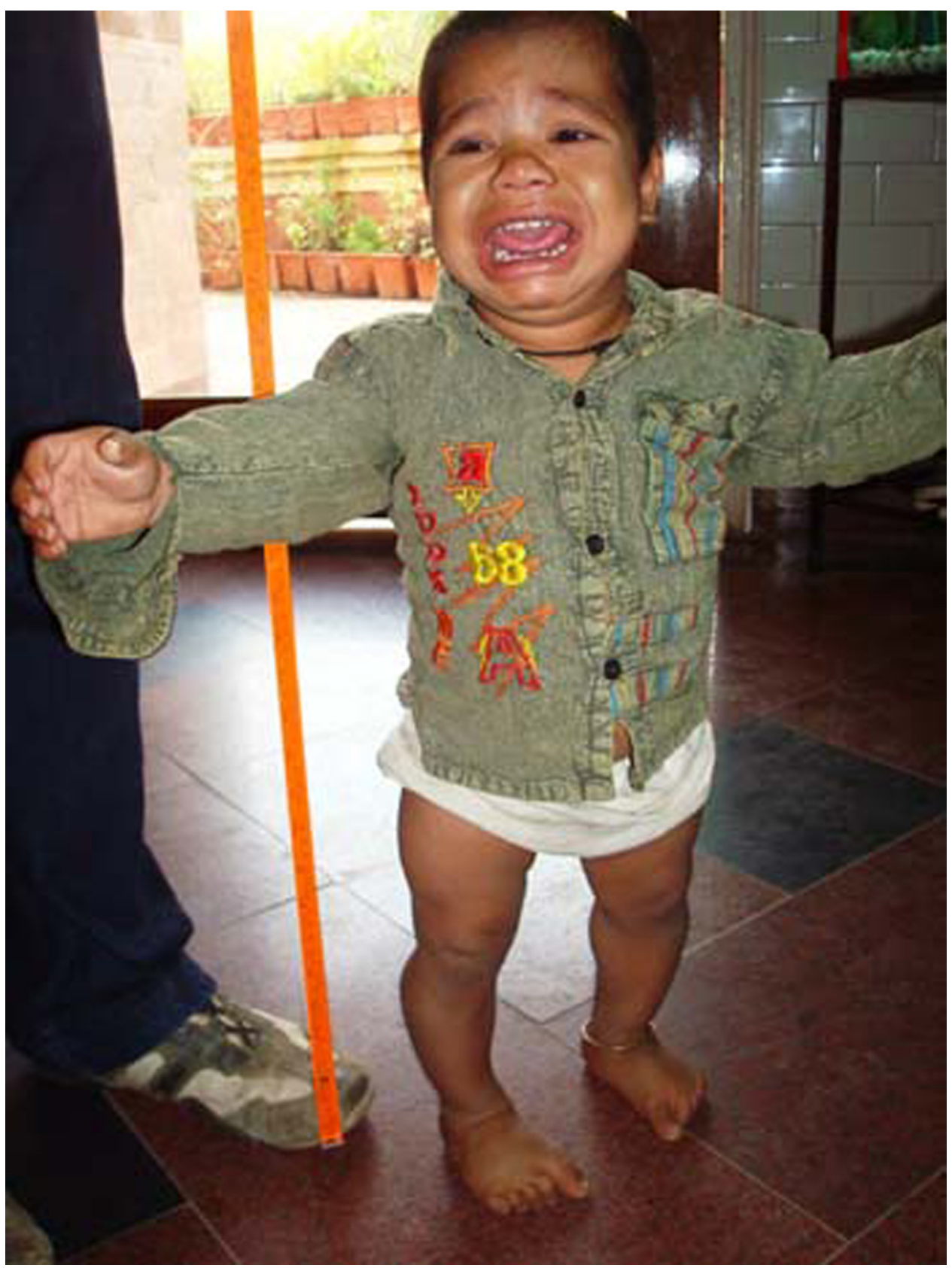

Figure 2 Short stature, calf muscle hypertrophy.

His developmental assessment showed normal gross motor milestones. He was able to draw a circle, but could not draw a square, he made a tower of six cubes and he spoke only monosyllables and could not speak sentences.

He showed hypertrophy of both the calf muscles. Gower sign was negative.

Rest of the examination was unremarkable.

\section{INVESTIGATIONS}

Complete blood count revealed haemoglobin of $9.0 \mathrm{~g} / \mathrm{dl}$, mean corpuscular volume was 90 . Electrolytes, creatine phosphokinase (CPK), chest $\mathrm{x}$-ray were normal.

$\mathrm{T} 3<10 \mathrm{ng} / \mathrm{dl}(60-200)$, T4 $0.7 \mu \mathrm{g} / \mathrm{dl}(4.5-12.0)$, thyroidstimulating hormone $>150 \mathrm{mIU} / \mathrm{ml}(0.30-5.5)$. Bone age: 6 months (figure 3).

\section{DIFFERENTIAL DIAGNOSIS}

The differential diagnosis for a child with the macroglossia, developmental delay and coarse features would include a mucopolysaccharidosis, Beckwith-Wiedemann or Simpson-Golabi-Behmel syndrome. All these could easily be differentiated on clinical grounds.

A combination of macroglossia, developmental delay, stunting and pseudohypertrophy of muscles clinches the diagnosis of Kocher-Debré-Semelaigne syndrome (KDS).

Muscle enlargement, stiffness and cramping are a constellation of findings seen in individuals with hypothyroidism. In adults, these findings are known as Hoffman syndrome, The absence of painful spasms and pseudomyotonia differentiates this syndrome from KDS. 


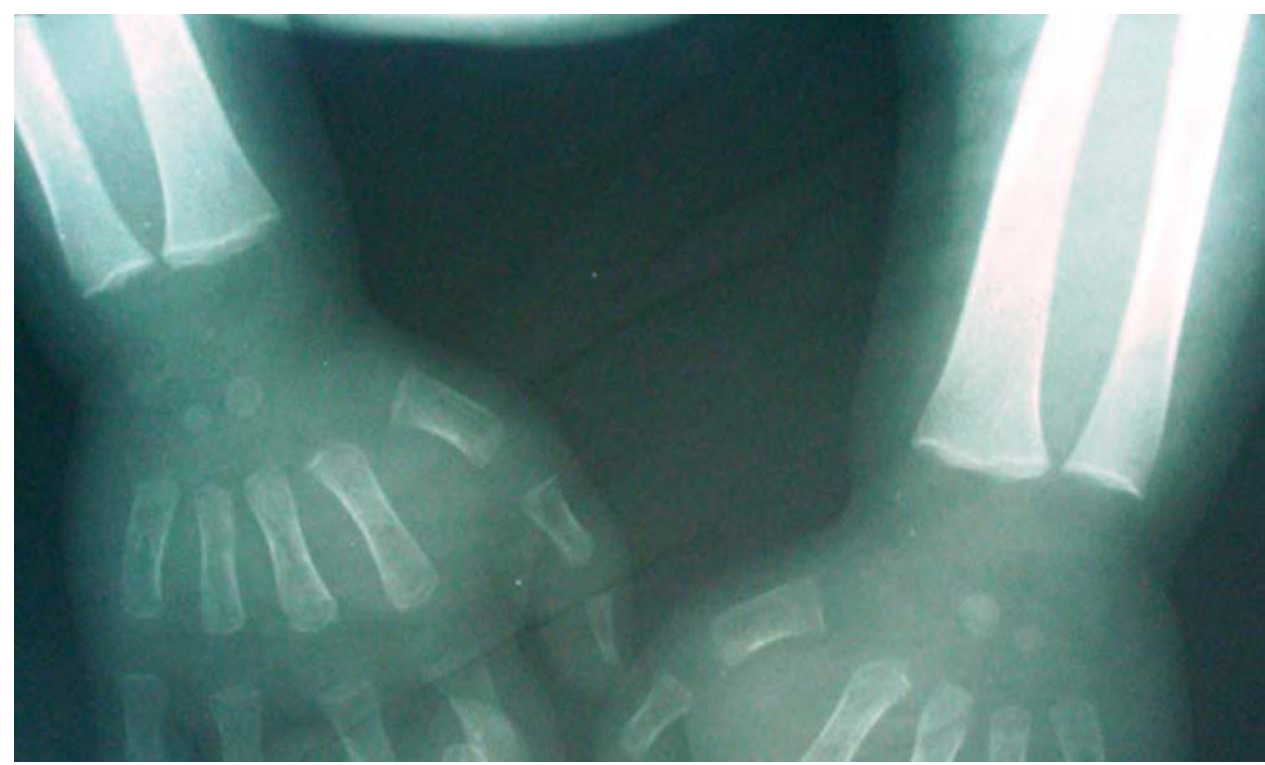

Figure 3 Bone age 6 months.

\section{TREATMENT}

This child was started on $50 \mu \mathrm{g}$ of levothyroxine daily.

\section{OUTCOME AND FOLLOW-UP}

The child came for the first follow-up 2 weeks after the start of treatment and his calf hypertrophy had reduced and he was more active and interactive.

\section{DISCUSSION}

The KDS is a myopathy of hypothyroidism in infancy or childhood characterised by muscular hypertrophy limited to lower extremity or being generalised, short stature and cretinism. Children with KDS usually present between 18 months and 10 years of age, but reports of cases diagnosed at earlier ages and even in neonates are also available. ${ }^{1}$ Kocher-Debré-Semelaigne syndrome comprised $18.7 \%$ of cases with a 2:1 female to male ratio. ${ }^{2}$ The patients present with the clinical features of hypothyroidism along with muscle pseudohypertrophy. ${ }^{3}$ The pseudohypertrophy involves muscles of extremities, limb girdle, trunk, hands and feet but it is more prominent in muscles of limbs; hence the athletic or Herculean look. ${ }^{4}$ Our patient presented with short stature, delayed mile stones and the pseudohypertrophy of calf muscle. He did not show any evidence of muscle weakness. His Gower sign was negative and his CPK was normal.

KDS has been found to be associated with all the usual causes of hypothyroidism presenting in childhood, namely, agenesis of thyroid gland, defective synthesis of thyroid hormone or autoimmune causes of hypothyroidism. The long-standing hypothyroidism is presumed to be responsible for the pseudohypertrophy of the muscles. ${ }^{1}$ Our patient remained undiagnosed till 4 years of age. Ignorance of the patient and non-availability of medical care in remote villages may be the reason for the hypothyroidism to be missed for so long in this patient.

Stiffness and aching of muscles are common and are worsened by cold temperatures. Delayed muscle contrac- tion and relaxation cause the slowness of movement and delayed tendon jerks. Muscle mass may be slightly increased, and the muscles tend to be firm. Rarely, a profound increase in muscle mass with slowness of muscular activity may be the predominant manifestation. ${ }^{5}$

Its pathogenesis is unknown; non-specific histochemical and ultrastructural changes seen on muscle biopsy return to normal with treatment. Affected patients have hypothyroidism of longer duration and severity. ${ }^{6}$ The treatment is usually effective in reverting back the muscle changes. This usually takes months. Our patient when he came for the first follow-up after 2 weeks did show clinical reduction in hypertrophy.

\section{Learning points}

- Hypothyroidism is generally associated with hypotonia but rarely may be associated with muscular pseudohypertrophy (KDS).

- The differential diagnosis for a child with the macroglossia, developmental delay and coarse features would include a mucopolysaccharidosis, Hoffman syndrome, Simpson-Golabi-Behmel syndrome or Beckwith-Wiedemann syndrome.

- Delay in diagnosis and seeking treatment may be responsible for KDS.

- Adequate replacement with thyroxin reverses these changes.

\section{Competing interests None.}

Patient consent Obtained.

\section{REFERENCES}

1. Tullu MS, Udgirkar VS, Muranjan MN, et al. Kocher-Debré-Semelaigne syndrome: hypothyroidism with muscle pseudohypertrophy. Indian J Pediatr 2003;70:671-3.

2. Unachak K, Dejkhamron P. Primary congenital hypothyroidism: clinical characteristics and etiological study. J Med Assoc Thai 2004;87:612-17. 


\section{BMJ Case Reports}

3. Tullu MS, Bavdekar SB. Kocher-Debré-Semelaigne Syndrome. In: Gupta S, ed. Recent Advances in Pediatrics, Special Volume on Pediatric Endocrinology. New Delhi: Jaypee Brothers 2004:159-62.

4. Virmani A, Gambhir A, lyer PU. Kocher-Debré-Semelaigne syndrome mimicking primary muscle disease. Indian Pediatr 1990;27:88-9.

5. Gregory A, Brent P, Larsen R, et al. Hypothyroidism and thyroiditis. In: Kronenberg HM, Melmed S, Polonsky KS, Larsen PR, eds. Kronenberg:
Williams Textbook of Endocrinology. Eleventh edition. Philadelphia: Saunders Elsevier 2008:381.

6. LaFranchi S. Hypothyroidism. In: Kliegman RM, Behrman RE, Jenson HB, Bonita FS, eds. Nelson's Text Book Of Pediatrics. Eighteenth edition. Philadelphia: WB Saunders 2008:2322.

This pdf has been created automatically from the final edited text and images.

Copyright 2010 BMJ Publishing Group. All rights reserved. For permission to reuse any of this content visit http://group.bmj.com/group/rights-licensing/permissions. BMJ Case Report Fellows may re-use this article for personal use and teaching without any further permission.

Please cite this article as follows (you will need to access the article online to obtain the date of publication).

Agrawal S, Thakur P. Kocher-Debré-Semelaigne syndrome. BMJ Case Reports 2010;10.1136/bcr.04.2010.2877, date of publication

Become a Fellow of BMJ Case Reports today and you can:

- Submit as many cases as you like

Enjoy fast sympathetic peer review and rapid publication of accepted articles

Access all the published articles

Re-use any of the published material for personal use and teaching without further permission

For information on Institutional Fellowships contact consortiasales@bmjgroup.com

Visit casereports.bmj.com for more articles like this and to become a Fellow 